\author{
Шевчук С. Ф., \\ кандидат фбілософбських наук, доцент, \\ доцент каффедри суспільних наук \\ житолирського національного агроекологічного університету
}

\title{
ФЕОФРАСТ ЯК ЗАСНОВНИК БОТАНІЧНОЇ НАУКИ
}

Анотація. У статті висвітлюються основні віхи життя та творчі здобутки видатного давньогрецького філософа і науковця, учня Платона й Аристотеля, Феофраста (Теофраста) з Ереса, що на острові Лесбос (372-287 роки до нашої ерие).

Метою роботи є доведення особливої ролі Феофраста як засновника ботанічної науки («батька ботаніки»). Для реалізації мети автор намагається вирішити такі завдання. Насамперед життєдіяльність Феофраста розглядається в контексті загальної соціально-культурної ситуації, яка мала місце на зламі двох епох Античності: завершення класики i народження нової елліністичної культури, у межах якої відбувалось інтенсивне формування спеціальних наук, що відокремлювались від натурфілософії.

Дружба та співпраця з Аристотелем не могли не лишити відбитка на творчості Феофраста. Тому автор вважала за доцільне здійснити часткове порівняння деяких фрагментів творів обох філософів, присвячених біологічній проблематиці («Історія тварин» Аристотеля та «Дослідження рослин» Феофраста). Унаслідок аналізу робиться такий висновок. У перших своїх роботах про рослинний світ Феофраст справді не надто відхилявся від існуючої традиції, загалом підтримуваної Аристотелем. Згідно із цією традицією рослинний світ розглядався майже аналогічно до тваринного. Однак у пізніх роботах філософ починає обережніше висловлюватись щодо вказаних аналогій; він поступово виробляє свій метод дослідження, суть якого у спостереженні над фактичним матеріалом. Як справжній науковець Феофраст сумнівається, вірить у незавершеність пізнання, вибудовує теоретичні висновки, відштовхуючись від спостережуваного емпірично. Водночас він уже не намагається підганяти факти під наперед вироблені готові схеми, як це мало місце в натурфілософії. Той факт, що в цих роботах він намагається уникати натурфілософської термінології, свідчить про еволюцію його поглядів та про впевненість ученого у своєму науковому методі дослідження, основаному на емпіричних спостереженнях і досвіді.

Отже, спираючись на аналіз досягнень Феофраста у вивченні рослинного світу, можна констатувати, що він перетворив ботаніку на самостійну науку, відокремлену від зоології та натурфілософії, поклавши в основу своєї наукової діяльності в цій галузі спостереження та досвід. Його внесок у закладення основ ботаніки є настільки вагомим, що дозволяє вважати вченого і філософа засновником (або «батьком») цієї науки.

Ключові слова: Феофраст, ботаніка, Аристотель, рослинний світ, «Дослідження рослин», натурфілософія, наука, метод спостереження.

Ставлення до науки в сучасному світі неоднозначне. 3 одного боку, визнається значущість наукових досягнень для життєдіяльності людства, з іншого - саме науку та техніку звинувачують у багатьох, зокрема глобальних, проблемах, що нависли над землянами. Вивчення історичних джерел виникнення i становлення наукового пізнання допомагає виявити особливість складного, суперечливого і водночас могутнього феномену сучасності - науки, іiі співвідношення та взаємодії 3 іншими формами пізнання.

Метою статті є доведення визначальної, основоположної ролі діяльності давньогрецького філософа Феофраста у становленні ботаніки як самостійної науки.

Для реалізації мети нами ставились такі завдання:

1) дослідити соціально-культурні особливості періоду давньогрецької історії, за якого відбувалось становлення окремих, спеціальних наук;

2) на підставі часткового порівняння природничо-наукових праць Аристотеля і Феофраста встановити схожість і відмінність методів дослідження, що застосовувались цими філософами;

3) констатувати вагомість і унікальність внеску Феофраста у процес становлення ботанічної науки, що дозволило назвати його «батьком ботаніки».

Проблеми становлення науки та їі співвідношення з філософією в період Античності досліджували відомі вчені: П. Таннері, А. Лосєв, А. Чанишев, А. Боннар, М. Сергієнко, І. Рожанський, Т. Кун, Дж. Холтон та інші.

Як відомо, колискою наукового пізнання стала антична культура, яка дала поштовх виникненню науки. Спочатку наукове пізнання було тісно переплетене з філософським. Прикладом цьому є науково-філософська система Аристотеля, який, з одного боку, ніби підсумував спроби наукового пізнання світу давніми греками, а 3 іншого - започаткував наступне велике розділення наук. «Сдина нерозчленована наука про природу, основоположником якої справедливо вважається Фалес Мілетський, підійшла в цей час до свого природного кінця. < .. > процес розчленування цієї науки почався раніше. Математика, яка була невід’ємною частиною космотеологічних спекуляцій ранніх піфагорійців, виділилась в кінці V ст. до н.е. в самостійну дисципліну, що мала свій предмет і специфічний метод дослідження» [1, с. 396].

В епоху Аристотеля на черзі стояло виділення й інших природничих наук: механіки, оптики, зоології, ботаніки, фізіології тощо. Про це свідчили самі назви Аристотелевих трактатів: «Фізика», «Про небо», «Метеорологіка», «Про виникнення тварин», «Історія тварин» та інші. Правда, Аристотель, чим би він не займався, ніколи не випускав із поля зору загальних положень, що становили основу його філософії. Його загальні філософські уявлення завжди наявні, навіть тоді, коли він обговорює конкретні проблеми природознавства. Цим Аристотель радикально відрізняється від більшості вчених 
епохи еллінізму, чи пізньої Античності. Для олександрійської науки вже була характерна спеціалізація, коли предмет науки цікавив дослідника безвідносно до яких-небудь філософських передумов. Наприклад, коли Ератосфен вимірював земну кулю, то він робив це цілком незалежно від натурфілософських чи космологічних гіпотез, яких було чимало за класичної епохи грецької культури. Незважаючи на те, що вчені цікавилися різними проблемами, у них не виникало думки про те, щоб звести всі свої знання в єдину систему.

Будучи надзвичайно чутливим до тенденцій свого часу, Аристотель вибудував свою філософську концепцію таким чином, щоб вона була найбільш комплементарною до науки, що народжувалась, і якнайбільш узгоджувалась із досвідом. Цей останній втілювався для Аристотеля у величезній кількості матеріалів, що стосувались різноманітних фактів і явищ природи, які «збирались ним із пожадливістю колекціонера, а потім осмислювались, класифікувались і пояснювались із тверезістю та вдумливістю справжнього природодослідника» [1, c. 398].

Книга історії становлення науки налічує багато яскравих сторінок. На одній із них зафіксовано життя і творчість досить відомого античного філософа Феофраста, фігура якого перебуває дещо в тіні його видатного друга і вчителя - Аристотеля. Однак саме йому випало стати засновником ботаніки як окремої самостійної науки та виробити новий, науковий, метод пізнання.

Феофраст (Теофраст) із Ереса, що на острові Лесбос (372-287 рр. до н.е.) - давньогрецький філософ, учень Платона і послідовник Аристотеля. Справжнє ім'я - Тіртам. Феофрастом (тобто таким, що божественно промовляс) його назвав Аристотель. Отримавши певні знання $з$ філософії на острові Лесбос, Феофраст переїхав до Афін, де навчався в Академії Платона. Там він здружився з Аристотелем, а згодом став його послідовником. Деякий час обидва філософи перебували в Македонії і на батьківщині Аристотеля, у місті Стагирі. Подальша тісна співпраця, що тривала приблизно дванадцять років, продовжувалась знову в Афінах. Згодом Аристотель призначив Феофраста керівником перипатетичної школи - Лікею, яку той успішно очолював понад тридцять чотири роки. Лікей відвідували майже дві тисячі учнів, серед яких були відомий комедіограф Античності Менандр, Епікур, Деметрій Фалерський та інші.

Деякий час друзі разом працювали в Мітілені, що на острові Лесбос, де інтенсивно займались природничо-науковими дослідженнями. Аристотель вивчав тварин, тоді як Феофрасту більше подобались рослини.

Про тісну дружбу і творчий тандем обох філософів свідчить і той факт, що Аристотель у своєму заповіті призначив Феофраста опікуном своїх дітей, заповів бібліотеку, оригінали праць і свій сад.

Подібно багатьом філософам античності Феофраст цікавився і висловлювався щодо різних проблем тогочасної філософії та науки. Спектр його дослідницьких інтересів можна простежити за назвами праць, яких, за свідченням Діогена Лаертського, налічувалось 227. Феофраст, як і Аристотель, написав першу та другу «Аналітику», «Топіку», «Аналіз силогізму», «Про підтвердження та спростування», «Софізм», «Природничу філософію», «Небесау», «Воду», «Вогонь», «Море», «Метеорологічні феномени», «Про душу», «Про досвід», «Про сприйняття» та інші [2, с. 218]. Хоча трактування окремих питань не надто відрізнялось від Аристотелевих, у них все ж можна виявити деякі додаткові деталі, а отже, можна говорити про зроблений крок уперед у певному напрямі.

Окремою сторінкою творчості Феофраста було написання біографій ранньоантичних філософів - Анаксимена, Анаксагора, Емпедокла, Архелая, Демокріта, Діогена Аполонійського й інших. Існує думка про те, що біографічна праця Феофраста «Про життєписи» була використана Плутархом для написання його відомих «Порівняльних життєписів».

Феофрасту належить невелика, але досить популярна і відома, робота - «Характери», у якій він подає тридцять типових характеристик людей, наприклад: «Скупий», «Хвалько», «Боягуз», «Нахаба» тощо. На думку деяких філологів, ця книжечка була створена переважно на матеріалі нової комедіï, у якій зображувались не стільки реальні живі характери, скільки типи. Однак навряд чи це так: у Феофраста й афінської реальності, яка його оточувала, було досить матеріалу для вироблення таких характеристик. Феофраст, будучи учителем і другом Менандра, відвідував різні кола афінського суспільства, а його гострий розум дозволяв вибирати 3 людського образу найсуттевіше та найхарактерніше. Він описував людей «типологічно» - так, як згодом описував рослини [3].

I все ж найголовнішими роботами Феофраста були його ботанічні твори, які дійшли до нас майже в повному обсязі, це: «Дослідження про рослини» у 9-ти книгах і «Причини рослин». Ось зміст першої роботи: у першій книзі - розмисли про частини рослин та їх морфологію; у другій викладено особливості догляду за садовими деревами; у третій подано опис лісових дерев; у четвертій описані рослини заморських країн і хвороби рослин; у п'ятій зібрані відомості про ліс та його використання; у шостій ідеться про кущі та квіти; у сьомій - про городні рослини та догляд за ними; у восьмій - про зернові, бобові та рільництво; у дев'ятій про лікарські трави. Ця робота в основному містить опис рослин та їх екологію [3].

«Дослідження про рослини» було другою ботанічною роботою Феофраста; перша, написана ним в молодості, має назву «Причини рослин». Ї̈ї зміст такий: у першій книзі йдеться про те, як рослини розмножуються та ростуть; у другій - про те, як рослини, переважно дерева, змінюються під впливом зовнішніх умов; у третій - про зміни, що виникають унаслідок культури; у четвертій - про різне насіння і про зернові рослини; у п'ятій - про надприродні явища в рослинному світі; у шостій - про смак та запах рослин [3].

Отже, одним із значних зацікавлень Феофраста був світ рослин. Цим світом цікавились $і$ до нього. Найперше це були люди, яких рослини цікавили із суто практичних міркувань, чия робота була пов'язана з рослинним царством: землероби, садівники, городники, виноградарі, лісоруби, ризотоми і фармакополи. Одним із джерел, із яких черпав свої знання про рослини Феофраст, були саме ці люди-практики. Іншим джерелом були знання, зафіксовані раніше філософами-натуралістами та мандрівниками. До Феофраста вже були зроблені деякі спроби якось систематизувати рослини. «Проте, незважаючи на все багатство ботанічних знань, зібраних до нього, Феофраст вступив у рослинне царство, як вступає мандрівник у невідому країну, де на кожному кроці його підстерігають боротьба, неочікувані й цікаві знахідки та відкриття» [3]. 
У перших чотирьох розділах своєї книги «Дослідження про рослини» Феофраст закладає фундамент для дослідження, якому присвячена решта цієї книги, що розповідає про частини рослин і є ніби паралельною до книги Аристотеля «Про частини тварин». Аристотель писав, що тварини розрізняються між собою життедіяльністю, характером і частинами. Головними категоріями для розрізнення рослин, за Феофрастом, $\epsilon$ «частини», «властивості», «виникнення» і «життя» («спосіб життя»). Як бачимо, явно простежується певна аналогія. Однак уже саме визначення поняття «частини в рослин» ставить дослідника у скрутне становище, адже частини у тварин завжди лишаються незмінними, тоді як рослини можуть втрачати свої частини вже протягом одного року.

Пояснивши поняття «частини» стосовно рослинного світу, учений описує рослину загалом, як суму цих частин, і розбиває рослинне царство на категорії. Сюди ж вплітаються і вказівки на те, що у сфері ботаніки потрібно діяти «типологічним методом». Опираючись на обраний метод, Феофраст поступово створюе схему, яка дозволяє розібратись у розмаїтті рослинного світу.

Визначивши, що саме і як потрібно досліджувати, Феофраст ще раз детально зупиняється на методі вивчення за схожістю, який, на думку вченого, можна застосовувати двояко: 1) порівнюючи одну рослину з іншою, 2) порівнюючи рослину із твариною. Цей останній спосіб Феофраст також застосовував, слідуючи за Аристотелем; він іноді розглядав тваринний і рослинний світ в аспекті деякої єдності. Однак водночас Феофраст був набагато обережнішим від свого вчителя.

На перший погляд може видатись, що Феофраст у всьому дотримувався вчення свого вчителя. Однак це не так. Наприклад, Аристотель уважав, що рослинний світ можна розглядати майже за повною аналогією із тваринним. Феофраст же зауважу, що «не варто розглядати однаково рослини і тварин, як у тому, що стосується відтворення, так і в іншому» [4, 1.1 (3)]. У своїй книзі «Дослідження про рослини» учений не раз застерігав проти проведення цілковитих аналогій: «Зайвим було 6 прагнути порівнювати те, що не може бути порівнюваним: так можна взагалі втратити предмет власних досліджень» [4, 1.1 (4)]. Або «<.. > якщо $€$ можливість розглядати щось за аналогією, то, як це роблять і під час розгляду тварин, слід для встановлення схожості порівнювати з найбільш схожим і найбільш досконалим» $[4,1.1$ (5)]. Отже, учений мав власну думку щодо можливості та необхідності аналогій, яка відрізнялась від позиції Аристотеля. Він неухильно дотримувався правила: не робити аналогій там, де їх немає.

Досліджуючи частини рослин і рослини загалом, Феофраст користується типологічним описом. Він зауважує, що «<..> знання стає виразнішим, якщо розділити предмет, що вивчається, на види. Першими і найголовнішими, які охоплюють майже всі рослини або більшість із них, будуть дерева, кущі, напівкущі та трави» $[4,1.3$ (1)]. Далі вчений дає визначення кожному виду, зазначаючи, що вони $€$ загальними і типологічними: «<...> Не потрібно прагнути до абсолютно точних визначень; визначення слід розуміти типологічно. Подібно слід чинити і з поділом рослин, наприклад, на культурні та дикі, плодові та неплодові, квітучі та ті, що неквітують, вічнозелені та ті, що втрачають листя. Рослини стають дикими чи культурними, очевидно, залежно від того, доглядають за ними чи ні» $[4,1.3(5)]$.
Зазначимо, що термінологія Феофраста не відрізняється суворістю. Здійснивши поділ рослин, він відразу ж застерігає, наприклад, що зміни, яким піддаються рослини, роблять можливим перехід з одного «виду» в інший, або, що для поділу можна було $б$ застосувати й інші критерії. Тому його поділ треба сприймати не як «абсолютно точний», а як типологічний.

Варто зауважити також, що слово «тип» у стародавніх греків мало дещо інше значення, ніж у нас. У них воно означало «контур», «начерк», «загальний план». Тобто коли йшлося про типологічний підхід, то це означало «говорити чи пояснювати взагалі, у загальних рисах, а не 3 повною точністю». Феофраст також протиставляв «загальний опис» «точному визначенню».

До речі, Аристотель, використовуючи слово «тип», говорить, що він дає лише ніби загальне окреслення різниці між тваринами й обіцяс уточнити надалі [5, 1.1, 487a12; 1.6, 491a8]. Феофраст же, навпаки, наполягає на тому, що він задовольняється «типами» - поняттями релятивними, такими, що не мають абсолютно чіткої визначеності. Очевидно, він уважав неможливим втиснути в чітко визначені категорії нескінченно мінливі та нестійкі форми рослинного світу, які визначались ним як «багатоманітне, складне і таке, що тяжко піддається визначенню» $[4,1.1 .10 ; 1.14,5]$. Відсутність суворості в його термінології, очевидно, можна пояснити прагненням створювати релятивні поняття з визначеним ядром, але без точних меж.

Обгрунтовуючи свої застереження стосовно «точних розмежувань», учений уводить і додає відразу ж винятки. Так, розмежовуючи рослини, що живуть на суші, i ті, що полюбляють вологі місци, він наводить приклад верби, вільхи, тамариску, які «є свого роду амфібіями» [4, 1.4 (2)]. Так само, уводячи нові поняття, учений діє дуже обережно. У таких випадках він уживає слова «якби»), «ніби»: у рослин «є ніби волокна» [4, 1.2 (5)]; «листя у сосни якби колючки» [4, 1.10 (4)]. На обережність дослідника спонукав і його основний «типологічний метод дослідження», за якого розгляд предмета в загальних рисах допускав багато відхилень: «сіра теорія» не окутувала «золото дерева життя» [4, 1.6 (20)]. Окрім того, він чітко бачив, де знань достатньо, а де їх не вистачає; і зауваження на кшталт: «це потрібно ще досліджувати», «цей пункт прояснений недостатньо», «тут $є$ деякі труднощі», - неодноразово трапляються в його книзі [4, 1.13,4; III.3.8; 5.6; IV.9.2; 10.4; 11.12].

Характерною особливістю Феофраста $є$ його наукова порядність та сумлінність. Виклавши й обгрунтувавши якесь положення, він завжди наводить і докази «проти», якщо такі є. Водночас йому притаманні точність і ясність опису. На цю рису вказує Стремберг, який зазначає, що опис коренів та їх характеристика для різних дерев Середземномор'я зроблені Феофрастом з такою повнотою і ретельністю, яка дотепер у цій сфері $€$ неперевершеною $[4,1.5(15)]$.

Спочатку Феофраст, справді, намагався дотримуватись учень філософів-натуралістів, що передували йому. Рослини для його попередників були переважно суто умоглядним предметом. Грецькі філософи, намагаючись пояснити світ і все в ньому, зводили суще до одного чи декількох елементів. Так, Емпедокл (492-432 pр. до н. е.) вбачав в основі світу чотири основні елементи: гаряче, холодне, сухе і вологе. Тварин і рослин він уважав схожими організмами. Менестор (приблизно 450 р. до н. е.) переніс поняття про холодну і гарячу сутність із тварин (як це було в Емпедокла) на рослини, і з того часу поділ рослин на «гарячі» та «холодні» загальновизнаний серед грецьких учених, що цікавилися питаннями ботаніки. 
Коли Феофраст пише, що в рослинах, як і у тварин, $є$ якась вроджена вологість і теплота [4, I.2 (4-6)], то першу ще можна було спостерігати, а от теплота є суто умоглядним припущенням. Це було відлуння тривалої усталеної традиції й особливо вчення Аристотеля, який наполягав на аналогії між тваринним і рослинним царствами. Вплив останнього в ранніх роботах Феофраста був значним: якнайбільше це виявлялось у прихильності до умоглядних теорій, у побудові яких реальні факти, які можна спостерігати емпірично, не брались до уваги. Про це свідчить, зокрема, і поширення Феофрастом на рослинність цілком умоглядної теорії самовільного виникнення, яку Аристотель використовував для пояснення походження деяких представників тваринного світу [5, 1.1.2].

Проте, чим більше заглиблювався Феофраст в емпіричне вивчення рослинного світу, тим більше відходив він від натурфілософських умовиводів, звільняючись від впливу свого вчителя і починаючи самостійно торувати свій науковий шлях. Метод, яким керуватиметься із цього часу Феофраст, полягатиме у спостереженні реальних фактів, а суто умоглядні теорії він вважатиме такими, що сприяють лиш безкінечним суперечкам. Відмовляючись від безпідставних «розмірковувань», Феофраст визнавав необхідність пізнання шляхом «чуттевого сприйняття», спостереження над реальними фактами.

У своїх ботанічних творах учений говорить, що наукові теорії повинні опиратись на емпіричну основу («О причинах», I. 1, 1; II. 3, 5), що емпіричні факти не повинні силоміць підганятись під теорію [4, I. 3, 5]. Правда, й Аристотель у своєму пізньому творі «Про виникнення тварин» рекомендував «довіряти більше відчуттям, ніж розмірковуванням» [5, III. 10. 760 b], однак ніколи не заперечував цінності дедуктивних побудов.

Крок за кроком Феофраст удосконалював свій метод: якщо раніше він використовував результати своїх спостережень для пояснення властивостей тільки умоглядного (пекучий смак рослини, наприклад, свідчить про її «теплу» природу), то згодом він уже без сумнівів пов'язує одне з одним реальні явища, які можна безпосередньо спостерігати. I саме вони стають предметом його пильної уваги науковця, а метафізиці в його пошуках та поясненнях більше немає місця. Саме тому в його пізніших роботах майже зовсім відсутне метафізичне поняття «першопричина», яке зводило явища до «начал», тобто первинних елементів природи (наприклад, «тепле» $\mathrm{i}$ «холодне» у рослинах). До речі, у своїх пізніх роботах Феофраст свідомо уникає самого слова «причина», тоді як у ранніх - воно незмінно повторюється.

Феофраста слушно називають «батьком ботаніки». Таку високу характеристику спадку вченого, значення його для формування ботанічної науки було дано йому ще за часів Античності. Однак і згодом, упродовж історії, саме так характеризували Феофраста, зокрема, на цьому наголошував великий біолог Карл Ліней. Ось як оцінює внесок античного вченого відома дослідниця і перекладачка із грецької М. Сергієнко: «Найголовніше - це те, що Феофраст зробив ботаніку самостійною наукою, відокремивши іiі від зоології і поклавши в основу своєї діяльності в цій галузі спостереження та досвід, почав працювати в ній методами, що виключали втручання в науку будь-якої метафізики» [3].

Справді, до Феофраста ботаніка була ніби додатком до зо0логії. Пояснюється це тим, що грецькі вчені-філософи схилялись до думки про те, що рослини і тварини є дуже схожими.
Уважалось, наприклад, що дерева можуть радіти і сумувати, що рослини і тварини складаються з тих самих елементів. Аристотель узагалі проводив дуже сміливу аналогію між рослиною і твариною; на його думку, на рослин перетворюються маленькі членистоногі тварини.

Саме Феофраст уперше довів принципову різницю між твариною і рослиною. У своїй роботі «Дослідження про рослини» він пише, що частини тварин завжди постійні, тоді як їх число в рослин невизначене та мінливе $[4,1.1 .4]$. Отже, не можна однаково розглядати рослин і тварин. Між частинами рослин і тварин може бути лише деяка аналогія, тобто схожість у функціях. Учений уперше встановив принципову різницю між «замкненою системою тваринного організму» $\mathrm{i}$ «відкритою системою рослини». Побачити ж аналогію та єдність рослин і тварин на клітинному рівні для античної науки було недосяжним. Акцент у дослідженні рослин Феофраст робив на природі самої рослини та її зв'язку з навколишнім середовищем (грунт, клімат, місцерозташування).

Висновки. Отже, науково-дослідницьку роботу Феофраста в галузі ботаніки можна вважати поворотним пунктом в істоpiї природничих наук. Якщо спостереження Аристотеля над природою і вражають своєю точністю, то їх пояснення не виходить за межі натурфілософських узагальнених і наперед складених схем. Лише Феофраст у своїх пізніх ботанічних роботах зумів підійти до вивчення явищ природи без схеми, а лише спираючись на метод дослідження, який полягав у точному спостереженні над організмами і встановленні зв'язків між ними та низкою зовнішніх чинників. Учений відійшов від суто теоретичних і дедуктивних побудов і вказав для природничих наук принципово інший метод вивчення явищ природи.

Окрім того, Феофраст у своїх ботанічних роботах уперше спробував об'єднати і звести в єдину систему численні розрізнені спостереження та вузькопрактичні знання про рослини, які були накопичені народами, що населяли Грецію та сусідні країни. Система ця була по-своєму продуманою і послідовною.

Звичайно, з висоти сучасної науки багато положень, висловлювань, узагальнень Феофраста щодо рослин видаються наївними та поверхневими. Однак, даючи оцінку ботанічній діяльності Феофраста, необхідно пам'ятати, що вчений користувався методами, прийомами, засобами та технікою наукового експерименту, які щойно народжувались, а отже, не могли бути досконалими. Попри все, рівень наукових знань, який був досягнутий «батьком ботаніки», $є$ значним та має свою непересічну цінність в історії ботанічних знань. Важливим спадок Феофраста $€$ ще й тому, що висвітлює джерела перших теоретичних положень у галузі ботаніки з давніх часів.

\section{Jimepamypa:}

1. Рожанский И. Развитие естествознания в эпоху античности. Ранняя греческая наука о «природе». Москва : Наука, 1979. 486 с.

2. Лаэртский Д. О жизни, учениях и изречениях знаменитых философов / общ. ред. и вступит. статья А. Лосева. АН СССР ; Ин-т философии. Москва : Мысль, 1979. 620 с.

3. Сергеенко M. Феофраст и его ботанические работы. URL: http//symposium.ru/ru/node/9616.

4. Феофраст. Исследование о растениях. URL: http//symposium.ru/ru/ node/9590.

5. Аристотель. История животных. Пер. с древнегреч. В. Карпова. Москва : Издательский центр РГГУ, 1996. 528 с. 


\section{Shevchuk S. Theophrastus as a botanic founder}

Summary. The article covers the basic marks of life and creative achievements of an outstanding ancient Greek philosopher and the scientist, pupil of Platon and Aristotle, Pheophrastus (Theophrastus ) from Eresos, that is on the Lesbos island.

The purpose of work lies in proving of Theophrastus especial role as a founder of botanical science ("Father of Botany"). For realization of this purpose, the author tries to solve the following tasks. First of all, life and activity of Theophrastus is being examined in a context of understanding the generasocial - cultural situation, which dominated on a joint of two epochs of antiquity: end of classic culture and the birth of a new Hellenic culture, within the limits of which there followed an intensive formation of special sciences, which separated themselves from natural physiophilosophy.

Friendship and cooperation with Aristotle couldn't but leave; imprint on the legacy of Theophrastus. Therefore, the author considered it as expedient to carry out partial comparison of some fragments of works of both philosophers, devoted to a biological problematic ("History of animals" by Aristotle and "Enquiry into Plants or Historia Plantarum" by Theophrastus). The following conclusion is made as the result of the analysis. In the first works on flora, Theophrastus did not really deviate from existing tradition, and, on the whole supported Aristotle. According to this tradition, approach to flora was treated almost similarly to animal world. However, in his late works, the philosopher started to express himself more cautiously concerning the specified analogies; he gradually works out a research method of his own, the essence of which lies in observation of actual plant material. As a true science officer, Theophrastus has doubts, trusts in incompleteness of knowledge, builds theoretical conclusions, making a start from empirical observance. Thus, he no longer tries to match the facts into the previously developed fixed schemes, as it was usual in natural physiophilosophy at that time. That fact, that in his works he tried to avoid terminology of natural physiophilosophy, testifies about the evolution of his outlook and about scientists; confidence in his scientific research method, based on empirical observance and experience.

Thus, basing on the analysis of Theophrastus; achievements in the flora studying, it is possible to state, that he transformed botany into an independent science, separated from zoology and natural physiophilosophy, putting observation and experience as a corner stone of his scientific activity in this branch of science. His contribution into the basics of botany is so powerful, that it allows us to count the scientist and the philosopher Theophrastus as the founder (or "father") of this science.

Key words: Theophrastus, botany, Aristotle, flora, "Enquiry into Plants", natural physiophilosophy, science, method of observation. 